\title{
ALEKSANDER GEMEL*
}

\author{
GRANICA I CENTRUM \\ PROBLEM STRUKTURY POJEĆC \\ W MODELU PRZESTRZENI POJĘCIOWYCH
}

\begin{abstract}
BORDERLINE AND CENTER

The Problem of Concepts Structure in the Conceptual Spaces Framework

One of the main aims of Peter Gärdenfors' theory of conceptual spaces is to provide, by means of the geometric methods of representation, a formal model for the prototype structure of concepts. However, his model is not free of theoretical problems regarding an adequate description of the psychologically correct structure of concepts. Therefore, the main purpose of this paper is to raise several questions concerning the relationship between the typicality function and the membership function, as well as to propose some solutions to these problems by offering a model that binds both functions formally. Thus, the proposed model is intended to complement Gärdenfors' conceptual spaces theory, in which the proper shape of both functions has not been sufficiently problematized. The second aim of the paper is to propose a new approach to vagueness, which is coherent with the formal requirements of the conceptual spaces framework, and at the same time is in line with the solution proposed in the first part of the text.
\end{abstract}

Keywords: conceptual spaces, similarity, membership, typicality, vagueness

Przez każde trzy punkty przechodzi prosta, o ile jest dostatecznie gruba

Hugo Steinhaus

Teoria przestrzeni pojęciowych Petera Gärdenforsa (2000, 2014) jest szczególnie ciekawą propozycją na mapie współczesnych dociekań kognitywistycznych. Stanowi próbę syntezy dwóch poglądów na naturę reprezentacji -

* Katedra Filozofii Współczesnej, Instytut Filozofii, Uniwersytet Łódzki, ul. Lindleya 3/5, 91-131 Łódź, e-mail: aleksander.gemel@gmail.com, ORCID: https://orcid.org/oooo0001-5869-7910. 
symbolizmu i koneksjonizmu. Dostarcza model, który ma pełnić funkcję pomostu między reprezentacjami opierającymi się na manipulacji abstrakcyjnymi symbolami a koneksjonistycznymi modelami sztucznych sieci neuronowych (Gärdenfors 2000: 43). Według Gärdenforsa jego propozycja nie stanowi konkurencji dla symbolizmu i koneksjonizmu, lecz ma je łączyć i uzupełniać. Przestrzenie pojęciowe mają bowiem wyjaśniać działanie tych elementów systemu poznawczego, z którymi symbolizm i koneksjonizm sobie nie radzą. Zdaniem Gärdenforsa oba podejścia mają trudności z tym, by w sposób właściwy, tj. zgodny z ustaleniami psychologii poznawczej, reprezentować zawartość pojęć, ich immanentną strukturę oraz genezę (Gärdenfors 2000: 37-40, 42-43). Niezależnie od głównego celu Gärdenforsa stawką całego jego przedsięwzięcia jest przede wszystkim dostarczenie koherentnego modelu reprezentacyjnego, który uwzględniałby psychologiczne wymogi funkcjonowania aparatu poznawczego człowieka. Wymogi te dotyczą głównie prototypowej struktury pojęć, której istnienie wspierane jest licznymi dowodami empirycznymi (Rosch 1975, Geeraerts 1985, Kleiber 2003, Lakoff 2011)'.

Zgodnie z głównym założeniem tezy o prototypowej organizacji pojęć probierzem przynależności kategorialnej pewnego elementu jest jego podobieństwo do najbardziej reprezentatywnych elementów danej kategorii (tzw. prototypów). Konsekwencją zróżnicowania stopnia reprezentatywności elementów kategorii jest ich większa wrażliwość na fenomen nieostrości. Zróżnicowanie to pociąga bowiem możliwość powstawania problemów z klasyfikacją przedmiotu o zbliżonym stopniu podobieństwa do więcej niż jednego prototypu. Według Gärdenforsa symbolizm i koneksjonizm mają problem z uwzględnieniem zjawisk prototypowych oraz procesu efektywnego uczenia (2000: 37-40, 42-43). Opracowana przez niego teoria przestrzeni pojęciowych jest de facto próbą stworzenia adekwatnego, formalnego modelu prototypowej struktury pojęć za pomocą metod geometrycznych. Projekt ten nie jest jednak wolny od trudności teoretycznych.

Głównym celem artykułu jest przedstawienie tych trudności oraz próba ich rozwiązania. Pierwszy problem dotyczy związku funkcji typowości danego przedmiotu z funkcją jego kategorialnej przynależności. Właściwy kształt obu

\footnotetext{
${ }^{1}$ Warto w tym miejscu wyraźnie zaznaczyć, że w zakresie psychologii pojęć ograniczam swoje rozważania do koncepcji i ustaleń Eleanor Rosch, do nich bowiem bezpośrednio odnosi się Gärdenfors. Należy jednak podkreślić, że choć teoria Rosch uchodzi za podręcznikowy przykład teorii kategoryzacji prototypowej, to nie stanowi ostatniego słowa w dziedzinie psychologii kategoryzacji. Od lat siedemdziesiątych ubiegłego wieku widać postęp badań w tym zakresie. Zaowocowały one licznymi rozwinięciami teorii Rosch. Dobrym przykładem jest tu teoria egzemplarzowa (Barsalou 1991). Na temat podobieństw i różnic między obydwiema teoriami por. Ross, Makin 1999, Minda, Smith 2002, Storms, De Boeck, Ruts 2000.
} 
funkcji nie został bowiem w teorii Gärdenforsa wystarczająco dobitnie przedstawiony, co naraża jego teorię na trudności analogiczne do tych sformułowanych przez Daniela N. Oshersona i Edwarda E. Smitha (1981). Pierwszym celem tekstu jest zatem opisanie modelu wiążącego obie funkcje. Drugi problem dotyczy możliwości uwzględnienia w teorii przestrzeni pojęciowych nieostrości drugiego rzędu. Moim celem jest też więc przedstawienie takiego modelu nieostrości, który byłby spójny z formalnymi wymogami teorii przestrzeni pojęciowych i jednocześnie pozostawałby $\mathrm{w}$ zgodzie $\mathrm{z}$ zaproponowanym powiązaniem funkcji przynależności i typowości.

Artykuł składa się z czterech części. Pierwsza poświęcona jest podstawowym założeniom dotyczącym metod modelowania reprezentacji poznawczych $\mathrm{w}$ teorii przestrzeni pojęciowej. W szczególności koncentruję się w niej na zaproponowanej przez Gärdenforsa formalnej reprezentacji prototypowej struktury pojęć modelowanej za pomocą podziału Woronoja. W drugiej części analizuję postawiony przez Oshersona i Smitha problem geometrycznej reprezentacji związku funkcji typowości i przynależności. Pokazuję, w jaki sposób odnosi się on również do przestrzeni pojęciowej. Przedstawiam szczegółowo krytykę Oshersona i Smitha (2.1), a następnie odpieram ich zarzuty (2.2) oraz przedstawiam propozycję formalnej reprezentacji w przestrzeni pojęciowej związku obu funkcji (2.2.1). Część trzecia artykułu zawiera propozycję modelowania zjawiska nieostrości opracowaną bezpośrednio dla teorii przestrzeni pojęciowych (Douven, Decock, Dietz, Égré 2013). Koncepcja ta jest jednak niewrażliwa na zjawisko nieostrości drugiego rzędu, a w konsekwencji nie daje się uzgodnić z rozwiązaniami zaproponowanymi w części drugiej. Stąd w części czwartej artykułu przedstawiam propozycję rozszerzenia modelu Douvena i współpracowników przez wprowadzenie progu wrażliwości poznawczej. Pokazuję też, że propozycja ta pozostaje $\mathrm{w}$ zgodzie $\mathrm{z}$ wszystkimi założeniami koncepcji Gärdenforsa.

\section{PRZESTRZENIE POJĘCIOWE JAKO MODEL DLA SEMANTYKI PROTOTYPOWEJ}

Najogólniej rzecz ujmując, teoria przestrzeni pojęciowych jest modelem reprezentacji szeroko pojętej treści pojęciowej. W odróżnieniu od innych funkcjonujących w kognitywistyce podejść do modelowania reprezentacji poznawczych - symbolizmu i koneksjonizmu - do porządkowania danych wykorzystuje kategorie zaczerpnięte z geometrii i algebry. Podstawową kategorią używaną w modelowaniu zawartości semantycznej w przestrzeni pojęciowej 
są wymiary jakościowe, które reprezentują własności modelowanych przedmiotów. Przedmioty reprezentowane są przy tym przez punkty, których przestrzenna lokalizacja uzależniona jest od właściwości opisywanych przez współrzędne na osi każdego z jakościowych wymiarów. Zbiór wymiarów wzajemnie zintegrowanych (tj. takich, które pozostają ze sobą w związku koniecznym, jak na przykład tembr, głośność i barwa dźwięku) tworzy domenę. Przykładem może być tu domena barwna konstytuowana przez trzy zintegrowane wymiary (jasności, odcienia, natężenia), w ramach której konkretny kolor stanowi punkt o określonych współrzędnych na osiach jakościowych wymiarów.

Zdaniem Gärdenforsa pojęcia w przestrzeni pojęciowej są reprezentowane przez wypukłe wielokąty, których układ jest określony przez umiejscowienie elementu prototypowego względem innych otaczających je prototypów w domenie. Rozwiązanie zaproponowane przez Gärdenforsa jest przy tym w pełni zgodne z prototypową teorią kategoryzacji, ponieważ prowadzi do niejednorodnej struktury kategorii, tj. struktury zróżnicowanej pod kątem kategorialnej reprezentatywności. Zróżnicowanie stopnia reprezentatywności jest możliwe, ponieważ w reprezentacji geometrycznej, w której pojęcia są modelowane za pomocą wielokątów wypukłych, punkty leżące $\mathrm{w}$ ich polu mogą zajmować mniej lub bardziej centralne położenie. Operacją wykorzystywaną przez Gärdenforsa do podziału przestrzeni i tym samym ukonstytuowania struktury kategorialnej danej domeny jest teselacja Woronoja. Podział ten polega na wyznaczeniu części w $n$-wymiarowej przestrzeni reprezentującej daną sferę poznawczą podmiotu bądź jedną z jego domen poznawczych. Formalnie rzecz biorąc, podział dla zbioru punktów $P$ (oznaczających prototypy) i funkcji odległości $d$ (reprezentującej stopień podobieństwa między przedmiotami) należących do przestrzeni Euklidesa (złożonej $\mathrm{z}$ wymiarów konstytuujących domenę poznawczą) przebiega zgodnie $\mathrm{z}$ formulą:

$$
\operatorname{Vor} P\left(p_{i}\right)=\left\{x \in E: \forall p_{j} \in P, d\left(x, p_{i}\right) \leq d\left(x, p_{j}\right)\right\}
$$

Reprezentujący pojęcie wielokąt w podziale Woronoja zostaje więc wyznaczony przez zbiór wszystkich punktów leżących bliżej danego punktu $p_{i}$ ze zbioru $P$ niż pozostałych punktów z tego zbioru. Dzięki teselacji Woronoja do reprezentacji genezy struktury kategorii wystarcza zatem jedynie wyróżnienie przykładów prototypowych danego pojęcia i psychologicznie rozumiana relacja podobieństwa między nimi². Rysunek 1 przedstawia przykładową teselację dla trzynastoelementowego zbioru $P$.

\footnotetext{
${ }^{2}$ Pod pojęciem „psychologicznie rozumianej relacji podobieństwa” rozumiem relację, która uwzględnia odkryte w naukach psychologicznych empiryczne właściwości podobienstwa. Jednym z klasycznych przykładów takich właściwości jest np. odkryta przez Tversky’ego
} 


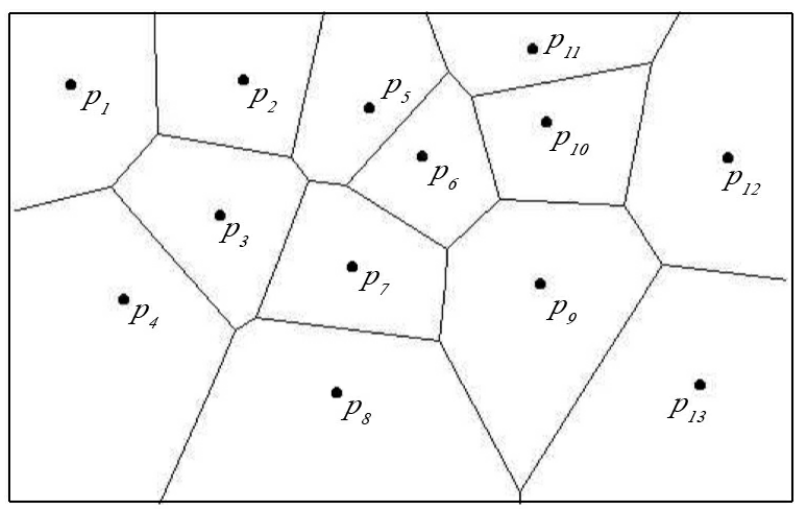

Rysunek 1. Teselacja Woronoja dla 13-elementowego zbioru $P$

Zaletą zaproponowanego rozwiązania jest jego niska złożoność obliczeniowa (Lee, Portier 2007)3. Przebiegający w zgodzie z modelem Gärdenforsa proces genezy struktury pojęciowej jest zatem spójny z zasadami ekonomii poznawczej. Co więcej, jak pokazali Okabe, Boots i Sugihara (1992), teselacja Woronoja na przestrzeni z metryką euklidesową zawsze dzieli ją na wielokąty wypukłe, a w konsekwencji wszystkie punkty leżące między dwoma dowolnymi punktami należącymi do obszaru VorP również należą do VorP. Kategoria wypukłości służy Gärdenforsowi do stworzenia tzw. kryterium P, zgodnie $\mathrm{z}$ którym jedynie wielokąty wypukłe reprezentują $\mathrm{w}$ przestrzeni pojęciowej własności naturalne (Gärdenfors 2000: 71). Kryterium P, co empirycznie wykazał w odniesieniu do domeny koloru Jäger (2010), jest immanentną cechą poznawczą struktur pojęciowych człowieka. Ze względu na empiryczną zasadność kryterium P rozważania podejmowane w dalszej części artykułu dotyczą jedynie przestrzeni pojęciowych z funkcją podobieństwa reprezentowaną przez odległość euklidesową.

(1977) niesymetryczność podobieństwa. Więcej na temat problemów związanych z modelowaniem tak rozumianej relacji podobieństwa w modelu geometrycznym i próbach ich przezwyciężenia por. Gemel 2016.

${ }^{3}$ Lee i Portier wykazali empirycznie, że proces uczenia opierający się na wypukłych kategoriach w przestrzeni pojęciowej jest o 41\% skuteczniejszy w porównaniu do metod uczenia maszynowego wykorzystujących wielowymiarową przestrzeń cech. 


\section{PROBLEM KSZTAŁTU FUNKCJI PRZYNALEŻNOŚCI}

Gärdenfors nie określa precyzyjnie kształtu funkcji przynależności obiektu do kategorii, nie definiuje również w sposób wyczerpujący jej związków z funkcją typowości. Jasne jest, że obie funkcje są ze sobą powiązane, skoro obie w jakimś sensie zależą od relacji podobieństwa do prototypu. Sposób ich powiązania nie jest jednak wyraźnie określony, pozostawiając pole do interpretacji. W najprostszym wariancie można uznać, że funkcja podobieństwa do prototypu, reprezentowana przez odległość w przestrzeni euklidesowej, odzwierciedla bezpośrednio zarówno typowość danego przedmiotu, jak i jego przynależność kategorialną. Co więcej, wydaje się, że interpretacja ta jest implicite przyjmowana przez Gärdenforsa. Przy takim rozumieniu obie funkcje pozostają tożsame z funkcją podobieństwa do prototypu i są reprezentowane przez odległość w przestrzeni podobieństwa.

Taka interpretacja narażałaby jednak model zaproponowany przez Gärdenforsa na zasadną z empirycznego punktu widzenia krytykę. Jednym z pierwszych przykładów takiej krytyki jest słynna i wciąż powtarzana w nowych odsłonach argumentacja Oshersona i Smitha (1981). Ich zdaniem oparta na geometrycznym modelu podobieństwa prototypowa teoria kategoryzacji jest nie do utrzymania $\mathrm{z}$ racji istniejącego w nim koniecznego utożsamienia funkcji typowości i przynależności kategorialnej. Utożsamienie takie nie wytrzymuje tymczasem weryfikacji empirycznej. O ile rzeczywiście można zgodzić się z twierdzeniem, że utożsamienie funkcji typowości i przynależności jest z empirycznego punktu widzenia sporym nadużyciem, o tyle, jak wykażę, utożsamienie takie nie jest koniecznym warunkiem każdej geometrycznie modelowanej semantyki prototypowej.

\subsection{PROBLEM UJEDNOLICENIA TYPOWOŚCI I PRZYNALEŻNOŚCI}

Jak słusznie wskazują krytycy propozycji utożsamienia funkcji podobieństwa do prototypu z funkcją przynależności kategorialnej, tego rodzaju rozwiązanie nie odzwierciedla psychologicznie adekwatnego procesu kategoryzacji. Często bowiem wyraźna różnica w typowości (podobieństwie) dwóch porównywanych przedmiotów nie pociąga ich odmiennej kategorialnej klasyfikacji. Na przykład, w ramach kategorii ptak wróbel znacznie przewyższa w typowości strusia, lecz oba bezdyskusyjnie należą do tej samej kategorii. Innymi słowy, wartość funkcji przynależności do kategorii ptak jest taka sama dla obu przedmiotów, tj. $\mu_{\text {Ptak }}($ Wróbel $)=\mu_{\text {Ptak }}($ Struś $)=1$, podczas gdy wartość funkcji typowości jest dla nich znacząco różna, tj. $\theta_{\text {Ptak }}($ Wróbel $)>\theta_{\text {Ptak }}($ Struś). Skoro zaś 
funkcja $\mu_{A}(x)$ przyjmuje odmienne wartości niż funkcja $\theta_{A}(x)$, to nie mogą one zostać utożsamione.

Co więcej, nawet gdyby ograniczyć rozważania jedynie do nieostrych predykatów języka naturalnego, których przynależność do kategorii - podobnie jak typowość - może zostać opisana w kategoriach stopniowalnych, to i tak można by dostrzec wyraźne różnice $\mathrm{w}$ kształcie funkcji przynależności i typowości, które według krytyków modelu geometrycznego przemawiają za ich rozdzieleniem. W wielu przypadkach funkcja przynależności przyjmuje wartości z przedziału $[0,1]$. Natomiast opierająca się bezpośrednio na podobieństwie funkcja typowości nie ma górnego ograniczenia4. Można bowiem wyróżnić wspólny wymiar podobieństwa nawet dla rzeczy nieprzynależących do wspólnej kategorii. Innymi słowy, można powiedzieć, że różowy jest podobny do czerwonego, lecz raczej trudno przyjdzie nam zgodzić się ze stwierdzeniem, że różowy to czerwony.

Tego typu przykłady można mnożyć, co jeszcze silniej potwierdza słuszność argumentacji wskazującej na problematyczność utożsamienia funkcji typowości z funkcją przynależności kategorialnej. Właściwym zamiarem krytyków modelu geometrycznego jest jednak udowodnienie, że model ten z konieczności zawiera takie utożsamienie. Starają się więc wykazać logiczną niemożliwość konstrukcji w modelu geometrycznym psychologicznie adekwatnej teorii prototypowej. Argumentacja Oshersona i Smitha jest tego najlepszym przykładem. Aby unaocznić problematyczność tej argumentacji, warto zobrazować ich krytykę na przykładzie ogólnych formalnych założeń modelu geometrycznej reprezentacji semantyki prototypowej. Te formalne założenia stanowią minimalny zbiór warunków, które każda geometryczna teoria prototypowa musi spełniać. Krytyka Oshersona i Smitha będzie więc zasadna tylko wtedy, gdy z tych podstawowych warunków będzie jednoznacznie wynikała konieczność utożsamienia funkcji przynależności kategorialnej z funkcją podobieństwa.

Formalnie rzecz ujmując, możemy opisać geometryczny model prototypowej kategoryzacji jako czwórkę:

$$
\begin{aligned}
& \mathfrak{P}:<D, d, p, \mu>\text {, gdzie: } \\
& D \text { - domena pojęciowa, } \\
& d-\text { funkcja odległości odwzorowująca } D \times D \text { w zbiór dodatnich } \\
& \quad \text { liczb rzeczywistych, reprezentująca miarę podobieństwa mię- }
\end{aligned}
$$

\footnotetext{
${ }_{4}$ Zważywszy, że ustalony sposób modelowania tej funkcji jest negatywny (tj. im większa jest jej wartość, tym mniej podobne do siebie są porównywane obiekty) oraz że o reprezentuje maksymalny stopień podobieństwa, to przyjmuje ona rozkład wartości z przedziału od zera do nieskończoności.
} 
dzy elementami $D$ (dla uproszczenia załóżmy, że jest ona również miarą typowości elementu z $D$ ),

$p$ - wyróżniony element prototypowy należący do zbioru $D$,

$\mu$ - funkcja kategorialnej przynależności odwzorowująca $D \mathrm{w}[0,1]$.

W tak opisanym modelu funkcja $d$, reprezentująca podobieństwo do prototypu, oprócz podstawowych aksjomatów przestrzeni metrycznej $\langle D, d\rangle$, tj.

$$
\text { minimalności }\left(\forall_{x} \forall_{y} \in D\right) d(x, y)=0 \Leftrightarrow x=y
$$

$$
\text { symetryczności }\left(\forall_{x} \forall_{y} \in D\right) d(x, y)=d(y, x)
$$

musi również spełniać warunek:

$$
\text { prototypowości }\left(\forall_{x} \forall_{y} \in D\right) d(x, p) \leq d(y, p) \rightarrow \mu(y) \leq \mu(x)
$$

Warunek prototypowości głosi, że stopień podobieństwa do prototypu jest powiązany ze stopniem kategorialnej przynależności. Zdaniem Oshersona i Smitha właśnie warunek (2) jest odpowiedzialny za utożsamienie funkcji podobieństwa do prototypu z funkcją przynależności kategorialnej.

$$
\text { 2.2. ODPOWIEDŹ NA KRYTYKE }
$$

Warunek prototypowości wbrew temu, jak go interpretują Osherson i Smith, nie oznacza jednak bezpośredniego przyporządkowania każdej wartości funkcji $d$ dokładnie tej samej wartości funkcji $\mu$. Nie utożsamia więc rozkładu wartości obu funkcji. Z warunku (2) nie wynika bowiem, że w sytuacji, kiedy stopień podobieństwa $x$-a do prototypu $p$ jest większy niż stopień podobieństwa $y$-a do $p$, wtedy także przynależność kategorialna $x$-a musi być większa niż $y$-a. Jeżeli podobieństwo między obydwoma przedmiotami jest dostatecznie niskie, to ich przynależność kategorialna może nie ulegać zmianie. Warunek prototypowości nie jest bowiem równoważny koniunkcji warunków (2.1) i (2.2), jak zdają się to niesłusznie pojmować Osherson i Smith:

$$
\left(\forall_{x} \forall_{y} \in D\right) d(x, p)<d(y, p) \rightarrow \mu(y)<\mu(x)
$$

$$
\left(\forall_{x} \forall_{y} \in D\right) d(x, p)=d(y, p) \rightarrow \mu(y)=\mu(x)
$$

lecz raczej ma postać równoważną warunkowi (2.3):

$$
\left(\forall_{x} \forall_{y} \in D\right) d(x, p) \leq d(y, p) \rightarrow \mu(y) \ngtr \mu(x)
$$


Warunek (2.3) głosi, że zarówno w przypadku, gdy stopień podobieństwa $x$ do prototypu $p$ jest większy niż stopień podobieństwa $y$ do $p$, jak i gdy są one równe, stopień przynależności $x$ jest nie mniejszy niż stopień przynależności $y$ (może być większy, ale może też być taki sam). Taka postać warunku prototypowości nie narusza więc żadnych intuicji związanych z psychologicznie rozumianym procesem kategoryzacji. Na pewno też nie prowadzi do opisywanej przez Oshersona i Smitha sytuacji, kiedy wraz ze wzrostem typowości również stopień przynależności kategorialnej musi automatycznie ulegać zmianie, a wartości obu funkcji (typowości i przynależności) muszą zostać utożsamione.

Drugi nieuzasadniony wniosek, który wyciągają Osherson i Smith, jest konsekwencją zbyt pochopnej interpretacji danych empirycznych. Uznają, że skoro funkcja przynależności do prototypu przebiega zgodnie z odmiennym rozkładem wartości niż - związana z podobieństwem do prototypu - funkcja reprezentująca typowość przedmiotu, to przynależność kategorialna nie może opierać się na relacji podobieństwa do prototypu i w rezultacie obie relacje muszą być ugruntowane w psychologicznie odmiennych procesach poznawczych5.

$\mathrm{Z}$ matematycznego punktu widzenia nie ma jednak żadnych powodów, aby odgraniczać i rozdzielać funkcję typowości od funkcji przynależności kategorialnej i tym samym traktować je jako niezależne i niemające na siebie wpływu fenomeny psychologiczne. Innymi słowy, z samego faktu występowania odmiennych wymagań formalnych względem konstrukcji funkcji reprezentujących przynależność i typowość nie wynika, że przynależność musi zostać oparta na odmiennych od typowości i niezależnych od relacji podobieństwa procesach poznawczych. U podstaw obu zjawisk (typowości i przynależności) może bowiem leżeć jeden proces (np. podobieństwo), lecz różne mogą być jego realizacje obliczeniowe zależnie od tego, czy dotyczy oceny typowości, czy kategorialnej przynależności.

Osherson i Smith zdają się jednak postulować coś odwrotnego. Mianowicie z samego odmiennego kształtu (tj. rozkładu wartości) obu funkcji wyciągają wniosek, że funkcje te muszą dotyczyć różnych zmiennych i tym samym opisywać niezależne procesy poznawcze. Wniosek ten jest jednak całkowicie nieuzasadniony i można go sfalsyfikować za pomocą prostego kontrprzykładu: weźmy dwie funkcje $t(x)=x^{e}$ oraz $p(x)=\frac{x^{e}}{1+x^{e}}$, obie one wiążą zmienną $x$ (którą można potraktować jako reprezentację rozkładu wartości podobieństwa do prototypu), czynią to jednak na różne sposoby, tj. zgodnie z odmien-

\footnotetext{
5 Oczywiście ostatecznym wnioskiem ma być stwierdzenie, że skoro z warunku prototypowości wynika, iż obie funkcje muszą zostać w modelu geometrycznym utożsamione, to należy model geometryczny odrzucić.
} 
nym rozkładem wartości. Pierwsza z nich nie ma górnej granicy, druga przyjmuje wartości z przedziału [o, 1]. Mimo różnych rozkładów obie funkcje mogą jednak być ze sobą powiązane w tym sensie, że wiążą tę samą zmienną. Innymi słowy, samo występowanie matematycznych różnic $\mathrm{w}$ rozkładzie wartości funkcji typowości i przynależności nie oznacza, że obie funkcje nie mogą wiązać się z oceną podobieństwa i że muszą odzwierciedlać całkowicie odmienne procesy psychologiczne. Różnice między rozkładem obu funkcji mogą bowiem wynikać, na przykład, z większej wrażliwości funkcji typowości na zmianę podobieństwa, niż ma to miejsce w przypadku funkcji przynależności. Wniosek Oshersona i Smitha, zgodnie z którym podobieństwo nie odgrywa żadnej roli w rozkładzie funkcji przynależności, a co za tym idzie, należy obie funkcje traktować jako zupełnie od siebie niezależne i ugruntowane w odmiennych procesach poznawczych, wydaje się zatem pochopny.

Argumenty Oshersona i Smitha mogą okazać się więc trafne jedynie w stosunku do naiwnej wersji teorii prototypowej, w której porządek typowości jest celowo utożsamiony $\mathrm{z}$ porządkiem przynależności kategorialnej. Przedstawiona przez nich argumentacja nie wyklucza jednak możliwości konstrukcji nienaiwnej teorii prototypowej w modelu geometrycznym, która bylaby wolna od wskazywanych problemów. Osherson i Smith przedstawiają więc nie tyle argumenty za niemożliwością konstrukcji prototypowej semantyki w geometrycznym modelu podobieństwa, ile jedynie argumenty za koniecznością bardziej precyzyjnego i subtelnego powiązania utożsamianych przez teorię naiwną porządków (tj. typowości i przynależności).

2.2.1. FORMALNA REPREZENTACJA FUNKCJI PRZYNALEŻNOŚCI I TYPOWOŚCI

Aby lepiej uzasadnić wysunięte wyżej zarzuty pod adresem argumentacji Oshersona i Smitha, przedstawię możliwość powiązania relacji typowości, przynależności i podobieństwa w modelu geometrycznym, która wbrew ich argumentacji nie prowadzi do konfliktu z danymi empirycznymi. Obie miary (tj. typowość i przynależność) mogą opierać się na wspólnej zmiennej wyrażonej przez funkcję podobieństwa do prototypu, a sam rozkład wartości obu funkcji może przebiegać według odmiennej intensywności (tj. przyjmować inną skalę wzrostu): typowość $=\theta$ (podobieństwo) oraz przynależność $=\mu$ (podobieństwo). $\mathrm{W}$ wypadku samego rozkładu wartości funkcji typowości nie ma żadnych formalnych i merytorycznych przeszkód, aby utożsamić ją z funkcją podobieństwa do prototypu, tj. $d(x)=\theta(x)$. Funkcja przynależności musi natomiast dawać możliwość wyjaśnienia empirycznie obserwowalnego zjawiska związanego z brakiem jednoczesnego spadku stopnia przynależności kategorialnej wraz z nieznacznym spadkiem stopnia podobieństwa przedmiotów należących do określonej kategorii. Taki spadek przynależności, rzecz jasna, 
będzie miał miejsce, lecz dopiero wraz z wyraźnym spadkiem typowości danego przedmiotu. Analogicznie minimalny wzrost typowości jakiegoś przedmiotu nienależącego do danej kategorii nie może przekładać się automatycznie na wzrost jego przynależności kategorialnej. Istotne jest także odzwierciedlenie efektu nieostrości i powiązanie go ze zmianą poziomu typowości przedmiotu.

Funkcją spełniającą takie założenia jest funkcja sigmoidalna. Definicję funkcji o takim kształcie zaproponował Lotfi A. Zadeh (1978: 6), wyróżniając trzy progi przynależności: $\alpha, \beta, \gamma$, przy czym $\beta=(\alpha, \gamma) / 2$ jest punktem krzyżowym, którego wartość wynosi o,5. Na tej podstawie możemy w analogiczny sposób zdefiniować funkcję przynależności kategorialnej łączącą typowość i stopniowalną przynależność do kategorii $A$ w oparciu o wspólny wymiar podobieństwa. Funkcja ta ma postać czterech warunków:

$$
\mu_{A}(x)= \begin{cases}1 & \text { dla } d(x)>d_{G} \\ 1-2\left(\frac{d_{G}-d(x)}{d_{G}-d_{D}}\right)^{2} & \text { dla } d_{G} \geq d(x)>d_{S} \\ 2\left(\frac{d(x)-d_{D}}{d_{G}-d_{D}}\right)^{2} & \text { dla } d_{S} \geq d(x)>d_{D} \\ 0 & \text { dla } d_{D} \geq d(x)\end{cases}
$$

gdzie $d(x)$ stanowi miarę podobieństwa do prototypu, z wyróżnionymi trzema progami: $d_{D}-$ dolny próg podobieństwa, poniżej którego $\mu=0, d_{G}-$ górny próg podobieństwa, powyżej którego $\mu=1$, oraz $d_{S}-$ punkt krzyżowy, w którym wartość $\mu=0,5$. Rysunek 2 przedstawia graficzną postać funkcji przynależności.

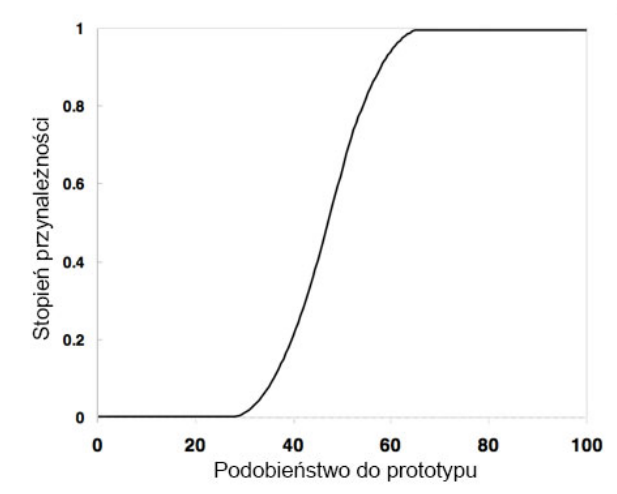

Rysunek 2. Wykres funkcji stopnia przynależności kategorialnej uzależnionej od podobieństwa do prototypu 
Funkcja ta spełnia wszystkie wymagania nakładane na adekwatną z psychologicznego punktu widzenia reprezentację prototypowej teorii kategoryzacji, wiążąc różne rozkłady podobieństwa i przynależności kategorialnej wspólną reprezentacją formalną. Równie istotne jest, aby funkcja ta była spójna z resztą założeń teorii przestrzeni pojęciowych, w tym z mechanizmem reprezentacji wyrażeń nieostrych.

\section{PROBLEM REPREZENTACJI NIEOSTROŚCI W MODELU GÄRDENFORSA}

Drugą zaletą teorii przestrzeni pojęciowej - obok możliwości włączenia prototypowości w model struktury kategorii - jest możliwość adekwatnej reprezentacji zjawiska nieostrości ${ }^{6}$. Co ciekawe, sam Gärdenfors nie opracowuje bezpośrednio modelu nieostrości w swojej głównej pracy Conceptual Spaces (Gärdenfors 2000)7. Jego model tworzenia struktury kategorii w oparciu o teselację Woronoja opiera się na zbiorze prototypów reprezentowanych jako punkty, dając w konsekwencji ostry podział domeny pojęciowej, z jednoznacznym przyporządkowaniem każdego punktu do określonego wycinka przestrzeni (por. Rys. 1). Choć efekt nieostrości granic kategorii nie jest bezpośrednio wpisany w propozycję teoretyczną Gärdenforsa, to teoria przestrzeni pojęciowych dość szybko doczekała się rozwinięcia również pod tym kątem. Propozycja wpisania reprezentacji nieostrości do przestrzeni pojęciowych opiera się na wykorzystaniu grup prototypowych jako generatorów klastrowych teselacji. Innymi słowy, zamiast zbioru prototypów $P=\left\{p_{1}, p_{2}, p_{3}, \ldots, p_{n}\right\}$ w roli generatorów występują zbiory grup prototypowych $P_{\text {klaster }}=\left\{\left\{\boldsymbol{p} \mathbf{1}_{1}, p 1_{2}, p 1_{3}, \ldots, p 1_{n}\right\}\right.$,

${ }^{6}$ Problemy dotyczące natury oraz genezy zjawiska nieostrości (przegląd stanowisk por. Kubiński 1958, Sorensen 2018) wykraczają poza zakres tematyczny tego artykułu. Zjawisko to jest tu traktowane jako fakt empiryczny dotyczący pojęć, w wypadku których istnieją tzw. interpretacyjne przypadki graniczne: np. termin „czerwony” jest nieostry, ponieważ istnieją przypadki czerwieni trudne do jednoznacznego zaklasyfikowania do jego zakresu. Ujęcie to jest w dużej mierze zgodne z pragmatyczną definicją zaproponowaną przez Shapiro, który powołując się na Vanna McGee i Briana McLaughlina (1994), twierdzi, że przedmiot $a$ może być uznany za przypadek graniczny predykatu $F$, ,jeżeli $F(a)$ jest nieokreślony (unsettled), tj. jeżeli $a$ nie jest zdecydowanie (determinately) $F$ ani nie jest zdecydowanie nie- $F$ " (Shapiro 2006: 7).

7 Pewną próbę rozwiązania tego problemu można znaleźć w u Gärdenforsa i Williams (2001). Opiera się ono na wykorzystaniu okręgów jako generatorów teselacji. Autorzy kładą jednak główny nacisk na kwestie złożoności obliczeniowej swojego modelu oraz wykazanie, że przy użyciu odpowiedniej metryki zaproponowana przez nich teselacja tworzy wielokąty wypukłe. Dowód tego ostatniego twierdzenia podali Okabe, Boots i Sugihara (1992). 
$\left.\left\{\boldsymbol{p 2} \mathbf{2}_{1}, p 2_{2}, p 2_{3}, \ldots, p 2_{n}\right\},\left\{\mathbf{p} \mathbf{3}_{1}, p 3_{2}, p 3_{3}, \ldots, p 3_{n}\right\}, \ldots,\left\{\mathbf{p n}_{\mathbf{1}}, p \mathrm{n}_{2}, p \mathrm{n}_{3}, \ldots, p \mathbf{n}_{n}\right\}\right\}$ (Douven, Decock, Dietz, Égré 2013). Rozwiązanie to pozwala uzyskać „wielowarstwowe” teselacje, które tworzą strukturą kategorialną o wyraźnie „szerszych” granicach mogących pomieścić półcień między ekstensją pozytywną i negatywną danego pojęcia (por. Rys. 3).

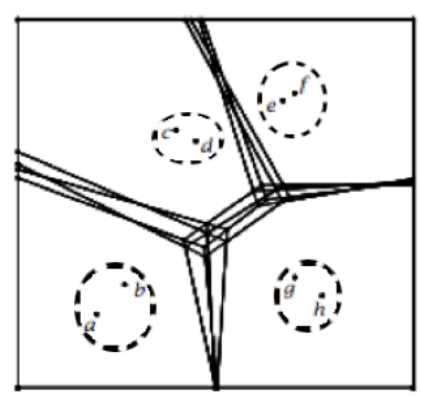

Rysunek 3. Diagram Woronoja wygenerowany przez zbiór $P_{\text {klaster }}$

Rozwiązanie to jest w wielu punktach zgodne z psychologicznymi wymogami dotyczącymi genezy pojęć. Jak pokazują badania z dziedziny psychologii poznawczej, proces genezy systemu kategorialnego człowieka zmierza do redukcji przypadkowości i złożoności rzeczywistości w zgodzie z zasadą ekonomii poznawczej, której istotą jest maksymalizacja ilości informacji reprezentowanej przez system poznawczy przy jednoczesnej minimalizacji poznawczego wysiłku potrzebnego do jej przetwarzania (Rosch 1978: 28). Najbardziej poznawczo wydajny sposób formowania systemu pojęciowego odbywa się więc, gdy przyswaja się jedynie niewielką grupę typowych przypadków i ekstrapoluje ich własności za pomocą funkcji podobieństwa na przypadki dostatecznie podobne. Naturalnie proces ten nie jest tak ścisły i precyzyjny, jak opisuje to punktowa teselacja Woronoja. Należy spodziewać się, że różnice w ramach struktury pojęciowej u różnych członków tej samej językowej populacji będą występowały zarówno w ocenie samych prototypów, jak i w czułości relacji podobieństwa, a w rezultacie będą przekładały się na różne usytuowanie i różną szerokość obszarów granicznych w indywidualnej strukturze kategorii. Co więcej, w przypadku gęstych domen pojęciowych (jak przestrzeń kolorów) muszą pojawić się przypadki o zbliżonym stopniu podobieństwa do więcej niż jednego prototypu (Berlin, Kay 1969: 10-12). Rzeczywisty proces kategoryzacji nie może się więc opierać na zbiorze pojedynczych przypadków prototypowych, lecz raczej na zbiorze grup prototypowych. W związku z tym adekwatna psychologicznie kategoryzacja w przestrzeni pojęciowej powinna być modelowana za pośrednictwem teselacji Woronoja - jest to zgodne zarówno z założe- 
niami Gärdenforsa, jak i z zasadą ekonomii poznawczej - lecz teselacja ta powinna być dokonywana za pomocą zbioru punktów wraz z ich najbliższym otoczeniem. Jest to bowiem zgodne zarówno z rozpiętością skali różnic indywidualnych między kategoryzującymi jednostkami, jak i z rozpiętością skali złożoności kategoryzowanej rzeczywistości.

Choć model klastrowej teselacji (Douven, Decock, Dietz, Égré 2013) spełnia te założenia, to nie jest on spójny z zaproponowaną w poprzednim rozdziale sigmoidalną funkcją przynależności kategorialnej $\mu_{A}(x)$. Nie jest to bowiem model przynależności rozmytej, lecz raczej przynależności, którą można by określić jako stopniowalną skokowo (por. Rys. 4).

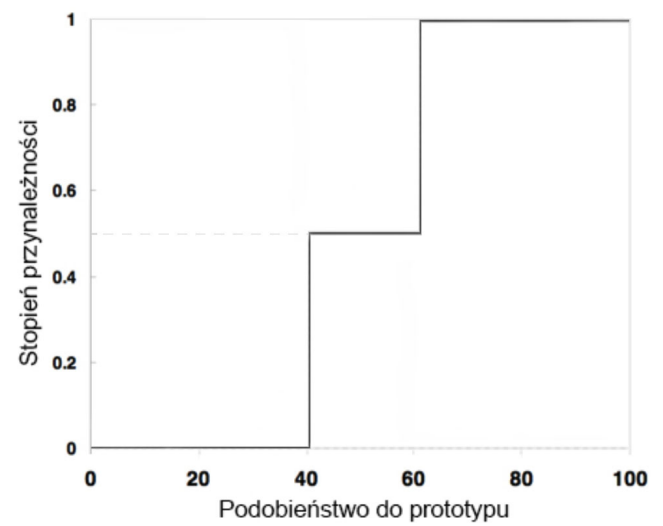

Rysunek 4. Wykres funkcji stopnia przynależności kategorialnej w relacji do podobieństwa do prototypu dla modelu teselacji klastrowej

Model zaproponowany przez Douvena i współpracowników nie jest więc w stanie uporać się z tzw. problemem nieostrości wyższego rzędu, tj. kwestią ostrości granicy między obszarem nieostrości a ekstensją pozytywną i negatywną danego pojęcia. Stanowi to poważny problem, ponieważ zdaniem wielu badaczy zjawisko nieostrości drugiego rzędu należy zaliczyć do samej istoty zjawiska nieostrości. Jak przekonują Rosanna Keefe i Peter Smith, „każda potencjalna teoria nieostrości musi uwzględniać jawny brak ostrych granic dla przypadków granicznych i być w stanie uporać się z problemem nieostrości wyższego rzędu" (1997: 15-16). Sami autorzy modelu teselacji klastrowej są zresztą świadomi ograniczeń zaproponowanego przez nich rozwiązania:

jeśli Sainsbury (1991) (oraz inni) mają rację, [...] to nieostrość nie jest tylko kwestią posiadania przypadków granicznych, ale także kwestią posiadania przez pojęcia rozmytych granic. Co gorsze, wydaje się, że ten tak zwany problem nieostrości wyższego rzędu może dotyczyć również naszego modelu, zważywszy, że klastrowe teselacje (collated diagrams) same w sobie nie przyczyniają się w żaden sposób do rozmycia (fuzzify) 
granic: nawet jeśli granice są faktycznie obszarami, to granice tych obszarów pozostają ostre (Douven, Decock, Dietz, Égré 2013: 152).

Moim celem jest więc rozbudowa modelu nieostrości Douvena i współpracowników, tak aby był zgodny z funkcją sigmoidalną. Warto przy tym zaznaczyć, że obrany przeze mnie sposób realizacji tego celu zakłada zarówno możliwie najmniejszą ingerencję w model Douvena i współpracowników, jak również $\mathrm{w}$ podstawowe założenia teorii przestrzeni pojęciowych ${ }^{8}$. Za obraniem takiej strategii przemawiają wydajność obliczeniowa oraz prostota modelu Douvena i współpracowników, a co za tym idzie jego poparta literaturą wysoka użyteczność w badaniach kognitywistycznych (Verheyen, Égré 2018, Gemel, Quinon 2019). Proponowane przeze mnie rozszerzenie modelu nieostrości sprowadza się do wprowadzenia jednej dodatkowej zmiennej określającej psychologicznie interpretowaną wartość progu czułości poznawczej.

\subsection{REPREZENTACJA NIEOSTROŚCI W PRZESTRZENI POJĘCIOWEJ}

Moje rozwiązanie, podobnie jak model Douvena i współpracowników (2013), opiera się na koncepcji klastrowej teselacji. Aby jednak teselacja mogła zdać sprawę z rozmycia granic, musi być spójna ze stopniowalną przynależnością kategorialną przebiegającą zgodnie z opisaną wyżej sigmoidalną funkcją $\mu_{A}(x)$. Proponuję wykorzystać w tym celu jako generatory teselacji obszary prototypowe o stopniowalnej przynależności. Podobnie jak w rozwiązaniu Douvena i współpracowników opieram się więc na założeniu, że nieostrość granic jest w pewnym sensie konsekwencją istnienia obszarów prototypowych. Inaczej jednak niż w koncepcji klastrowej teselacji proponuję przyjąć, że również sam obszar prototypowy jest pojęciem nieostrym, tj. pojęciem o stopniowalnej przynależności. $\mathrm{W}$ proponowanym modelu nieostrość granic jest więc wynikiem występowania stopniowalnego obszaru prototypowego $\mathrm{w}$ centrum każdego nieostrego pojęcia. Zakładam, że elementy grupy prototypowej będą również charakteryzowały się stopniem prototypowości 9 , co będzie znajdowało swoje odzwierciedlenie w postaci mniej lub bardziej centralnego położe-

\footnotetext{
${ }^{8}$ Poza zakresem tego artykułu pozostaje więc odniesienie do wszelkiego rodzaju możliwych uogólnień teorii przestrzeni pojęciowych (oraz innych geometrycznych modeli podobieństwa) wykorzystujących pojęcia i narzędzia zaczerpnięte z topologii czy też jej lokologicznych uogólnień (Breysse, De Glas 2007). Choć bez wątpienia rozważania na temat zasadności i możliwości topologicznego lub lokologicznego uogólnienia przestrzeni pojęciowych mogłyby przynieść obiecujące wyniki teoretyczne, to kwestie te wykraczają poza tematykę podejmowanych tu dociekań.

${ }_{9}$ Zdaniem Geeraertsa (1989) sama prototypowość jest w istocie również zjawiskiem prototypowym.
} 
nia wyróżnionych elementów $\mathrm{w}$ ramach grupy ${ }^{10}$. Zgodnie z tym założeniem właściwość prototypowości dla konkretnego przedmiotu $x$ będzie w dużej mierze zależna od indywidualnej wartości progu wrażliwości poznawczej (właściwej dla osoby dokonującej kategoryzacji). Na próg ten składają się takie elementy, jak na przykład czułość relacji podobieństwa właściwa dla danego podmiotu, jego spostrzegawczość, wielkość jego bazy doświadczeń, czynniki kulturowe bądź kontekst sytuacyjny. Wszystkie te elementy wpływają na faktyczny rozmiar i ksztalt grupy prototypowej osoby dokonującej kategoryzacji.

Próg wrażliwości poznawczej jest więc - przynajmniej teoretycznie zmienną, której faktyczna wartość dla poszczególnego indywiduum może zostać zmierzona i ujęta w kategoriach psychofizycznych. Na potrzeby konstrukcji modelu próg ten, jako pewna wartość uogólniona dla całej populacji, będzie reprezentowany w sposób probabilistyczny. Za takim rozwiązaniem stoją nie tylko względy praktyczne. Na etapie konstrukcji modelu nie można bowiem wykluczyć, że próg czułości poznawczej ma faktycznie ruchomą naturę, a co za tym idzie, że jego adekwatna reprezentacja powinna być realizowana właśnie za pomocą środków probabilistycznych. Innymi słowy, dopuszczam możliwość, że faktyczna wartość progu może być ruchoma w sensie jej zależności od takich zmiennych czynników, jak aktualne uwarunkowania kontekstowo-sytuacyjne, bieżące uwarunkowania poznawczo-fizjologiczne podmiotu czy też - dyktowane względami pragmatycznymi - intencjonalne modyfikacje własnej struktury pojęciowej, dokonywane na bieżąco przez podmioty biorące udział w procesie komunikacji (np. gdy w celu uzyskania zgody w dyskusji godzimy się nazywać dany kolor mianem typowej czerwieni, choć w innych okolicznościach nie bylibyśmy skłonni tego uczynić). Rzecz jasna, moim celem nie jest wyszczególnienie tutaj całej listy takich potencjalnych czynników wpływających na zmienność progu wrażliwości poznawczej. Proponuję natomiast model, który bierze pod uwagę potencjalnie płynną naturę owego progu wywołaną przez czynniki podobne do wymienionych ${ }^{11}$. Środkiem do osiągnięcia tego celu jest właśnie probabilistyczna reprezentacja progu wrażliwości poznawczej, która wiąże się z koniecznością definiowania na bieżąco rozkładu prawdopodobieństwa dla potencjalnych wartości progowych, a nie przyjmowania ustalonej stałej wartości dla poszczególnego indywiduum.

${ }^{10}$ Założenie to potwierdzają klasyczne badania Berlina i Kaya (1969) dotyczące efektów prototypowych w domenie kolorów: niezależnie od różnic kulturowych i językowych badani odnosili się do praktycznie tych samych egzemplarzy prototypowych.

${ }^{11}$ Model taki jest zgodny z założeniami Geeraertsa (1985), który słusznie zauważa, że sztywność modelu kategoryzacji czyni go wysoce nieefektywnym, ponieważ - chociażby z racji złożoności przepływu strumienia doświadczeń - rzadko mamy do czynienia z wysoce powtarzalną korelacją cech. 
Przy tych założeniach funkcja przynależności elementu $x$ do danego obszaru prototypowego $O_{i}$ równa jest wartości prawdopodobieństwa, że wartość $d\left(x, p_{i}^{\max }\right)$ (tj. reprezentowane przez odległość podobieństwo $x$ - $a$ do prototypu o najwyższej wartości) jest mniejsza lub równa niż aktualny próg wrażliwości poznawczej $\varepsilon_{i}$, który jest określony ze względu na rozkład prawdopodobieństwa $\delta_{\varepsilon_{i}}$ (por. Rys. 5).
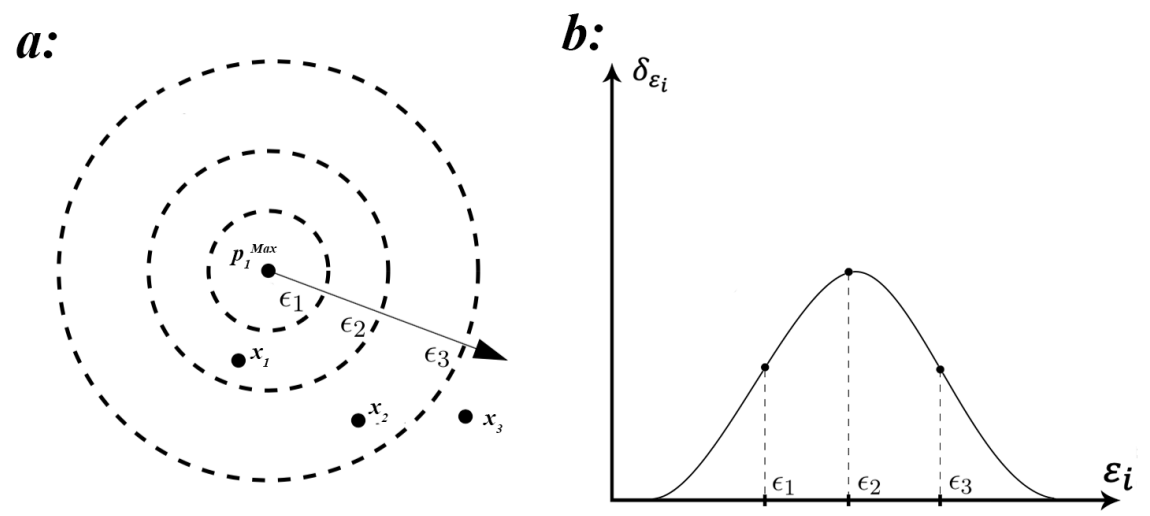

Rysunek 5. (a) Reprezentacja grupy prototypowej $O_{i}$ z trzema wyróżnionymi przykładowymi progami czułości poznawczej $\varepsilon_{1}, \varepsilon_{2}$ oraz $\varepsilon_{3}$, (b) Przykładowy wykres funkcji rozkładu prawdopodobieństwa $\delta_{\varepsilon_{i}}$ dla poszczególnych możliwych wartości (długości) progów $\varepsilon_{1}, \varepsilon_{2}, \varepsilon_{3}$

Pojęcie progu poznawczego $\varepsilon_{i}$ intuicyjnie można wyrazić jako dopuszczalny stopień podobieństwa $x$ do $p_{i}^{\max }$ (tj. centralnego elementu obszaru $O_{i}$ ), czyli taki, który wystarcza do zaliczenia $x$-a do obszaru prototypowego $O_{i}$. Przynależność do $O_{i}$ jest więc wyrażona stopniem prawdopodobieństwa, że próg poznawczy będzie nie mniejszy niż odległość $x$-a od $p_{i}^{\max }$. Formalnie rzecz biorąc, funkcja przynależności $x$ do $O_{i}$ może więc zostać wyrażona jako:

$$
\mu_{O_{i}}(x)=\operatorname{Pr}\left(\varepsilon_{i}: d\left(x, p_{i}^{\max }\right) \leq \varepsilon_{i}\right)
$$

Wielkość progu poznawczego będzie zależna od skorelowanej z nim funkcji gęstości prawdopodobieństwa $\delta_{\varepsilon_{i}}$. Funkcja ta będzie zachowywała się w taki sposób, że wraz ze wzrostem odległości przedmiotu $x$ od prototypu o najwyższej wartości $p_{i}^{\max }$ wartość funkcji $\mu_{O_{i}}(x)$ będzie maleć, ponieważ prawdopodobieństwo, że $x$ będzie usytuowany w obszarze określonym przez próg poznawczy, również stopniowo ulega zmniejszeniu (por. Rys. 6a). Prototypy $p_{i}^{\max }$ o najwyższej wartości, jako elementy poznawczo wyróżnione w ramach przestrzeni pojęciowej, będą miały maksymalną wartość prawdopodobień- 
stwa znalezienia się w progu poznawczym, a co za tym idzie, ich wartość funkcji przynależności do obszaru prototypowego (tj. $\mu_{O_{i}}$ ) będzie wynosiła 1. Wraz z oddalaniem się przedmiotu $x$ od prototypu $p_{i}^{\max }$ wartość funkcji przynależności do $O_{i}$ będzie dla $x$ maleć (por. Rys. 6a):

a:

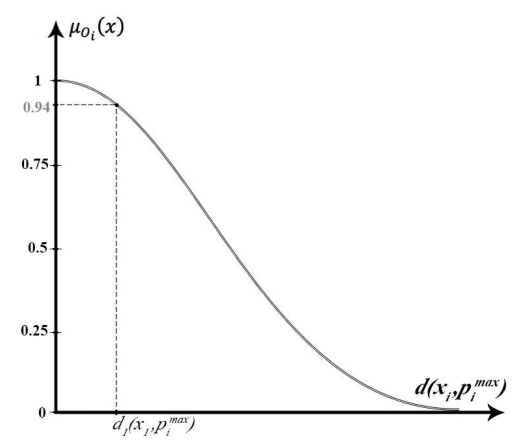

b:

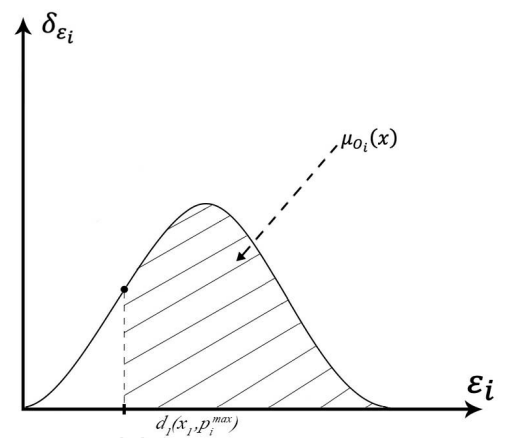

Rysunek 6. (a) Wykres zależności wartości przynależności $x$ do grupy prototypowej od jego odległości od $p_{i}^{\text {max }}$ : dla przykładowego $x$-a o odległości $d_{1}$ przynależność do grupy prototypowej wynosi o,94. (b) Wykres zależności odległości przedmiotu $x$ od prototypu o najwyższej wartości od rozkładu prawdopodobieństwa progu czułości poznawczej; dla tego samego $x$-a o odległości $d_{1}$ od $p_{i}^{\max }$ przynależność do grupy prototypowej można wyrazić również jako zakreskowany obszar.

Korzystając więc z rozkładu funkcji gęstości prawdopodobieństwa przypisanej do progu wrażliwości poznawczej, przynależność do obszaru prototypowego można również wyrazić jako obszar pod wykresem funkcji przedstawionej na Rysunku 6a, dany wzorem:

$$
\mu_{O_{i}}(x)=\int_{d\left(x, p_{i}^{\text {max }}\right)}^{\infty} \delta_{\varepsilon_{i}}\left(\varepsilon_{i}\right) d \varepsilon_{i}
$$

W rezultacie obszar prototypowy można zdefiniować jako trójkę:

$$
O_{i}=<p_{i}^{\max }, d, \delta_{\varepsilon_{i}}>
$$

Użycie tak zdefiniowanych obszarów prototypowych w roli generatorów teselacji pozwala na uzyskanie nieostrej struktury kategorii ze stopniowalnym progiem przynależności opisanym przez funkcję $\mu_{A}(x)$. Uogólniona teselacja Woronoja wykorzystująca zbiór obszarów prototypowych, tj. $O=\left\{O_{1}, O_{2}, \ldots, O_{n}\right\}$ (z których każdy $O_{i}$ jest zbiorem prototypów, tj. $O_{i}=\left\{p_{i 1}, p_{i 2}, \ldots, p_{i n}\right\}$, o stopniu przynależności do $O_{i}$ wyrażonym funkcją $\mu_{O_{i}}$ ), należący do przestrzeni $E$ z opisaną na niej funkcją podobieństwa $d$ przebiegałaby zgodnie z formułą:

$$
\operatorname{Vor}_{A}\left(O_{i}\right)=\left\{x \in E: \forall p_{i} \in O_{i}, \forall p_{j} \in O_{j} d\left(x, p_{i}\right) \leq d\left(x, p_{j}\right)\right\}
$$


Ponieważ prototypy o niższej wartości $\mu_{O_{i}}(x)$ będą zajmowały bardziej peryferyjne miejsce $w$ ramach obszaru prototypowego danego pojęcia, to ich położenie $\mathrm{w}$ przestrzeni podobieństwa również będzie mniej centralne niż na przykład położenie prototypów $p_{i}^{\max }$, tj. o wartości $\mu_{o_{i}}(x)=1$. Wartość funkcji $\mu_{o_{i}}(x)$ określonego prototypu wpływa zatem na jego usytuowanie w przestrzeni podobieństwa. Oznacza to, że od wartości funkcji $\mu_{O_{i}}$ poszczególnych prototypów zależy położenie i wzajemny układ generowanych przez teselację granic kategorii. Innymi słowy, układ prototypów (a ściślej rzecz biorąc wartości ich funkcji przynależności), które generują teselację, będzie wpływał na wartość funkcji kategorialnej przynależności punktów leżących w obrębie obszarów granicznych.

Przy założeniu, że mamy dwie grupy prototypowe $O_{\mathrm{A}}$ i $O_{\mathrm{B}}$, z których każda składa się z $n$ prototypów $\left\{p_{\mathrm{A}}{ }^{1}, p_{\mathrm{A}^{2}}, p_{\mathrm{A}^{3}}, \ldots, p_{\mathrm{A}^{\mathrm{n}}} \mathrm{n}\right.$ i $\left\{p_{\mathrm{B}^{1}}, p_{\mathrm{B}^{2}}, p_{\mathrm{B}^{3}}, \ldots, p_{\mathrm{B}}^{\mathrm{n}}\right\}$ przynależących odpowiednio do $O_{\mathrm{A}}$ i $O_{\mathrm{B}} \mathrm{w}$ stopniu określonym odpowiednio przez funkcję $\mu_{O_{A}}\left(p_{A}^{i}\right): \mathrm{E} \rightarrow[1, \mathrm{o}]$ oraz $\mu_{O_{B}}\left(p_{B}^{i}\right): \mathrm{E} \rightarrow[1,0]$, przynależność $x$-a do kategorii $A$, generowanej przez uogólnioną teselację Woronoja w oparciu o grupy prototypowe $O_{\mathrm{A}}$ i $O_{\mathrm{B}}$, wynosi:

$$
\mu_{V r_{A}}(\mathrm{x})=\left\{\begin{aligned}
1-\frac{\left[\frac{\mu_{O_{B}}\left(p_{B}^{i}\right)}{\mu_{O_{A}}\left(p_{A}^{i}\right)}\right]}{2} & \text { dla } \mu_{O_{A}}\left(p_{A}^{i}\right) \geq \mu_{O_{B}}\left(p_{B}^{i}\right) \\
\frac{\left[\frac{\mu_{O_{B}}\left(p_{B}^{i}\right)}{\mu_{O_{A}}\left(p_{A}^{i}\right)}\right]}{2} & \text { dla } \mu_{O_{A}}\left(p_{A}^{i}\right)<\mu_{O_{B}}\left(p_{B}^{i}\right)
\end{aligned}\right.
$$

Funkcja ta jest tożsama z zaproponowaną w podrozdziale 2.2.1 funkcją $\mu_{A}(x)$. Oznacza to, że układ kategorii generowany przez teselację Woronoja przybiera postać nieostrej struktury z płynnymi progami granicznymi między poszczególnymi kategoriami. W rezultacie teselacja przeprowadzana z wykorzystaniem obszarów prototypowych przyjmuje następującą postać (Rys. 7).

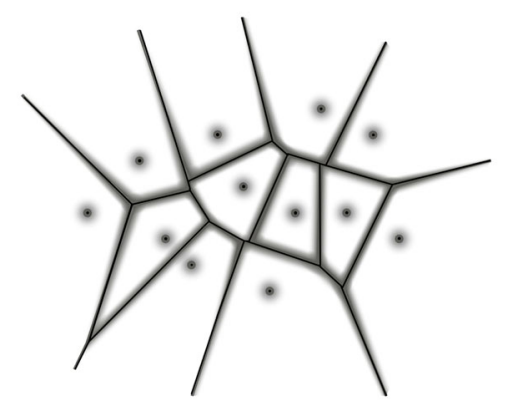

Rysunek 7. Diagram Woronoja z wykorzystaniem $O_{i}$ jako generatorów teselacji 
Taka forma teselacji umożliwia wpisanie nieostrości drugiego rzędu w model Douvena i współpracowników. Nowatorstwo tego rozwiązania polega na subtelniejszej formalnej reprezentacji struktur pojęć nieostrych w ramach teorii przestrzeni pojęciowych bez konieczności modyfikacji jej podstawowych pojęć. Ponadto proponowany model może okazać się także przydatny do rozwiązania pewnych szczegółowych problemów kognitywistyki, ponieważ można go wykorzystać do precyzyjnego wyrażenia w przestrzeni pojęciowej poznawczych przybliżonych systemów wiedzy rdzennej, takich jak ANS (approximate number system) (Cantlon, Platt, Brannon 2009). ANS jest bowiem odpowiedzialny za nieostre reprezentacje liczebności zbioru, które bez efektywnych metod modelowania nieostrości drugiego rzędu były niezwykle kłopotliwe do wyrażenia w ramach teorii przestrzeni pojęciowych. Dzięki zaproponowanemu rozwiązaniu postulowane przez Charlesa Gallistela i Rochel Gelman (2000) ujęcie reprezentacji ANS w kategoriach wyrażeń zbliżonych do liczb rzeczywistych może okazać się o wiele naturalniejsze w modelu przestrzeni pojęciowych. Krótko mówiąc, rozszerzenie teorii Gärdenforsa otwiera cały wachlarz nowych praktycznych możliwości wykorzystania przestrzeni pojęciowych, z którymi teoria ta nie radzila sobie do tej pory najlepiej.

\section{PODSUMOWANIE I DALSZE BADANIA}

Celem artykułu było rozwiązanie dwóch problemów w ramach teorii Gärdenforsa: (i) kwestii związku typowości i przynależności kategorialnej oraz (ii) możliwości ujęcia w jego modelu nieostrości drugiego rzędu. Zaproponowany przeze mnie model opiera się na ujęciu kategorialnej przynależności jako sigmoidalnej funkcji typowości wygenerowanej przez podział Woronoja, przeprowadzany za pomocą grup prototypowych, do których przynależność zależy od relacji wrażliwości poznawczej. Główną wartością tego rozwiązania - oprócz spójności z ugruntowaną w badaniach psychologicznych teorią prototypu oraz podstawowymi założeniami przestrzeni pojęciowych - jest jego empiryczna weryfikowalność. Pojęcia wykorzystane do konstrukcji modelu opierają się bowiem na zmiennych, które są możliwe do operacjonalizacji w kategoriach mierzalnych. Dalsze badania powinny więc w pierwszej kolejności koncentrować się właśnie na skorzystaniu z tej możliwości, tj. sprawdzeniu, na ile faktycznie próg wrażliwości poznawczej (przekładający się na wielkość grupy prototypowej) wpływa na wartość funkcji przynależności kategoryzowanych obiektów oraz czy funkcja ta wykazuje sigmoidalną zależność od typowości obiektu, korespondującą z danymi empirycznymi. Otwarte po- 
zostają również teoretyczne pytania o możliwość i celowość topologicznego rozszerzenia modelu przestrzeni pojęciowych. Choć uogólnienia tego rodzaju mogą wiązać się z koniecznością rezygnacji z części podstawowych formalnych założeń modelu Gärdenforsa, to wydaje się, że mogą one dostarczyć ciekawych wyników teoretycznych.

\section{BIBLIOGRAFIA}

Barsalou L. W. (1991), Deriving Categories to Achieve Goals, „Psychology of Learning and Motivation" 27, 1-64. https://doi.org/10.1016/Soo79-7421(08)60120-6

Berlin B., Kay P. (1969), Basic Color Terms, Berkeley: University of California Press.

Breysse O., De Glas M. A. (2007), New Approach to the Concepts of Boundary and Contact. Toward an Alternative to Mereotopology, „Fundamenta Informaticae” 78(2), 217-238.

Cantlon J. F., Platt M. L., Brannon E. M. (2009), Beyond the Number Domain, „Trends in Cognitive Sciences" 13(2), 83-91. https://doi.org/10.1016/j.tics.2008.11.007

Douven I., Decock L., Dietz R., Égré P. (2013), Vagueness. A Conceptual Spaces Approach, „Journal of Philosophical Logic” 42(1), 137-16o. https://doi.org/10.1007/s10992-0119216-0

Gallistel C. R., Gelman R. (2000), Non-verbal Numerical Cognition. From Reals to Integers, „Trends in Cognitive Sciences” 4(2), 59-65. https://doi.org/10.1016/S1364-6613(99) 01424-2

Gärdenfors P. (2000), Conceptual Spaces. On the Geometry of Thought, Cambridge: MIT Press. https://doi.org/10.7551/mitpress/2076.001.0001

Gärdenfors P. (2014), Geometry of Meaning. Semantics Based on Conceptual Spaces, Cambridge: MIT Press. https://doi.org/10.7551/mitpress/9629.001.0001

Gärdenfors P., Williams M. A. (2001), Reasoning about Categories in Conceptual Spaces [w:] Proceedings of the 17th International Joint Conference on Artificial Intelligence, IJCAI'O1, vol. 1, B. Nebel (ed.), San Francisco: Morgan Kaufmann, 385-392.

Geeraerts D. (1985), Paradigm and Paradox. Explorations into a Paradigmatic Theory of Meaning and its Epistemological Background, Leuven: Leuven University Press.

Geeraerts D. (1989), Introduction. Prospects and Problems of Prototype Theory, „Linguistics” 27, 587-612. https://doi.org/10.1515/ling.1989.27.4.587

Gemel A. (2016), Problem geometrycznej reprezentacji podobieństwa $w$ koncepcji przestrzeni pojęciowych Petera Gärdenforsa, „Filozofia Nauki” 24(3) [95], 25-41.

Gemel A., Quinon P. (2019), Magnitude and Number Sensitivity of the Approximate Number System in Conceptual Spaces [w:] Conceptual Spaces. Elaborations and Applications, M. Kaipainen, F. Zenker, A. Hautamäki, P. Gärdenfors (eds.), Cham: Springer, 183-203. https://doi.org/10.1007/978-3-030-12800-5_10

Jäger G. (2010), Natural Color Categories Are Convex Sets [w:] Logic, Language, and Meaning, M. Aloni, H. Bastiaanse, T. de Jager, K. Schulz (eds.), Berlin: Springer, 11-20. https://doi.org/10.1007/978-3-642-14287-1_2

Keefe R., Smith P. (1997), Introduction. Theories of Vagueness [w:] Vagueness. A Reader, R. Keefe, P. Smith (eds.), Cambridge: MIT Press, 1-57. 
Kleiber G. (2003), Semantyka prototypu, kategorie i znaczenie leksykalne, tłum. B. Ligara, Kraków: Universitas.

Kubiński T. (1958), Nazwy nieostre, „Studia Logica” VII, 115-179. https://doi.org/10.1007/ BFo2548937

Lakoff G. (2011), Kobiety, ogień i rzeczy niebezpieczne. Co kategorie mówią nam o umyśle, tłum. M. Buchta, A. Kotarba, A. Skucińska, Kraków: Universitas.

Lee I., Portier B. (2007), An Empirical Study of Knowledge Representation and Learning within Conceptual Spaces for Intelligent Agents [w:] 6th IEEE/ACIS International Conference on Computer and Information Science, R. Lee, M. U. Chowdhury, S. Ray, T. Lee (eds.), Los Alamitos: IEEE Computer Society, 463-468. https://doi.org/10.1109/ ICIS.2007.57

McGee V., McLaughlin B. (1994), Distinctions without a Difference, „Southern Journal of Philosophy" 33(S1), 203-251. https://doi.org/10.1111/j.2041-6962.1995.tboo771.x

Minda J. P., Smith J. D. (2002), Comparing Prototype-Based and Exemplar-Based Accounts of Category Learning and Attentional Allocation, „Journal of Experimental Psychology. Learning, Memory, and Cognition" 28(2), 275-292. https://doi.org/10.1037/o2787393. 28.2.275

Okabe A., Boots B., Sugihara K. (1992), Spatial Tessellations. Concepts and Applications of Voronoi Diagrams, New York: John Wiley \& Sons.

Osherson D. N., Smith E. E. (1981), On the Adequacy of Prototype Theory as a Theory of Concepts, „Cognition” 9(1), 35-58.

Rosch E. (1975), Cognitive Representation of Semantic Categories, „Journal of Experimental Psychology” 104(3), 192-233. https://doi.org/10.1037/0096-3445.104.3.192

Rosch E., (1978), Principles of Categorization [w:] Cognition and Categorization, E. Rosch, B. B. Lloyd (eds.), Oxford: Lawrence Erlbaum, 27-48.

Ross B. H., Makin V. S. (1999), Prototype versus Exemplar Models in Cognition [w:] The Nature of Cognition, R. J. Sternberg (eds.), Cambridge: MIT Press, 205-241.

Sainsbury M. (1991), Is There Higher-Order Vagueness?, „Philosophical Quarterly” 41(163), 167-182. https://doi.org/10.2307/2219591

Shapiro S. (2006), Vagueness in Context, Oxford: Oxford University Press. https://doi.org/ 10.1093/acprof:oso/9780199280391.001.0001

Sorensen R. (2018), Vagueness [in:] The Stanford Encyclopedia of Philosophy (Summer 2018 Edition), E. N. Zalta (ed.). https://stanford.io/3e47wF6.

Storms G., De Boeck P., Ruts W. (2000), Prototype and Exemplar-Based Information in Natural Language Categories, „Journal of Memory and Language” 42(1), 51-73. https://doi.org/10.1006/jmla.1999.2669

Tversky A. (1977), Features of Similarity, „Psychological Reviews” 84(4), 327-352. https://doi.org/10.1037/0033-295X.84.4.327

Verheyen S., Égré P. (2018), Typicality and Graded Membership in Dimensional Adjectives, „Cognitive Science” 42(7), 2250-2286. https://doi.org/10.1111/cogs.12649

Zadeh L. (1978), Fuzzy Sets as a Basis for a Theory of Possibility, „Fuzzy Sets and Systems” 1 , 3-28. https://doi.org/10.1016/0165-0114(78)90029-5 